\title{
EXPLORING THE RELATIONS AMONG MISCIBILITY, POLARITY, STRUCTURE AND MOLECULAR INTERACTION
}

\author{
Danilo José Ferreira Pinto, Maria Fernanda Penteado \\ Lamas, Valéria Campos dos Santos, Agnaldo Arroio \\ University of São Paulo, São Paulo, Brazil
}

\begin{abstract}
This work explores the relation among the concepts miscibility, polarity, structure and molecular interaction presented by students from the third year of a high school. They were challenged to trace a strategy to explore the comportment of the alcohols: ethanol, propan1-ol, butan-1-ol, pentan-1-ol and 2-methylpropan-2-ol in aqueous systems. With the solutions and glassware necessary, students realized that, even though they were polar molecules, some of these are not miscible in water. Inside the multimodal conception was possible to diagnose the learning and misconceptions behaviour by activities of investigation by practice, modelling and discursive production. The relation between polarity, interaction solution-solvent and the molecular structure were the argumentative tools used by students to explain the results obtained in the experiment.
\end{abstract}

Key words: misconceptions, modelling, multimodality, solutions.

\section{Introduction}

In some cases, the student is placed as a passive listener to the information supplied by the teacher. In this perspective, there is no way to consider the previous knowledge that students have built throughout life. Nevertheless, Gonçalves and Marques (2006) argue that the learning comes from the closeness of the relationship between what the learner already knows and what he is learning. Thus, it is essential to consider that students are not just reproducers of meanings, but also builders of these. The use of multiple modes of communication (such as experiments, videos, modelling activities, among others) assists this task, as it considers the heterogeneity of the classroom to foster the discursive production (Kress et al, 2001). According Paivio (1986), multimodal learning environments use verbal and non-verbal modes to represent the content knowledge. CATLM is the CognitiveAffective Theory of Learning with Media proposed by Moreno (2005), presents a model of learning in an interactive multimodal environment (Figure 1). 


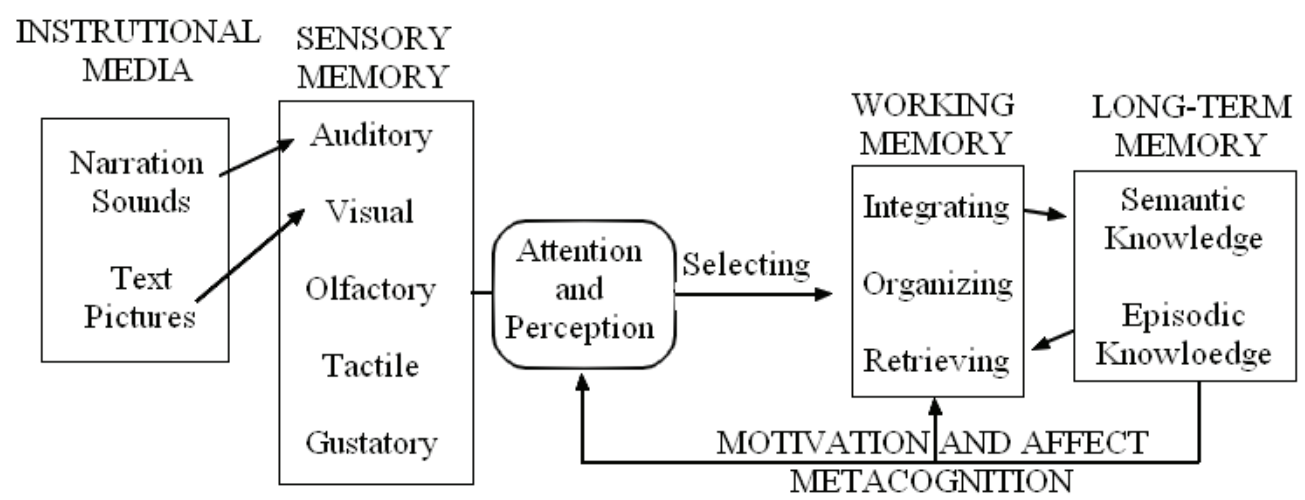

Figure 1: Model for learning in an interactive multimodal environment, according to a CATLM (Moreno and Mayer, 2007).

One of the modes of communication used was the experimental inquiry. Marzano (2000) describes an experimental inquiry as a "process of generating and testing hypotheses for the purpose of understanding some physical or psychological phenomenon". According to Izquierdo et al. (1999) research is the most important part of experimentation, as the content to be investigated is motivated by the context and inquiries proposed by the teacher. In this perspective, Hofstein and Lunetta (2004) add that the Inquiry Based Learners must guide the concerns of the students. Bachelard (1996) defends that an investigative experiment is one that fails, as it requires a braking stimulus and subsidizes the development of new techniques, theories and social discourses. Similarly, Gonçalves and Marques (2006) criticize the experimental classes like "cake recipe" because the proponents expect that the knowledge be constructed by mere observation and interpretation of data.

The experiments in chemistry teaching require the student to correlate the submicroscopic with phenomena. This must be guided by the construction of a mental model (Chittleborough and Treagust, 2007). Rapp (2007) proposes that a mental model is a knowledge structure organized and internalized relationships with individual case, time and space formed by fragments of external information. In this process, often arise explanations that differ from those scientifically accepted, the misconceptions.

Among the various chemical contents, Mendes (2007) reports that the main difficulties in understanding the concepts of solubility and miscibility are related to the submicroscopic level, specifically in the process of building mental models.

Carmo et al. (2010), conducted targeted activities after the diagnosis of misconceptions inside the theme solutions. Thirty three percent of the students enhanced to complex levels of cognition by the study of the dissolution and the interactions among the constituent particles.

This work aims to use the multimodal concept as a tool that integrates the construction of mental models about the idea of miscibility and polarity by students. The instructional media used for stimulating the sensory memory, promoting motivation and affection in the students thoughs integrating; organizing and retrieving information about concepts are the experimental inquiry, activity of modeling, writing and discursive production. The identification of misconceptions and knowledge agrees in difference modes of communication is also desired. 


\section{Methodology of Research}

The School of Application, associated to the Faculty of Education of the University of São Paulo (USP-FE), provides elementary and high school. One third of students are children of employers FE-USP, other third are children of USP workers in general and one third is the neighborhood community. This is a public institution with no costs to the users.

The activities were implemented in two meetings of 1 hour and 40 minutes each. With an average of 40 students per class separates in five groups, the intervention was applied to the four classes of the senior year of high school. At first, students investigated the behavior of the alcohols: ethanol, propan-1-ol, butan-1-ol, pentan-1-ol and 2-methylpropan-2-ol in aqueous systems. Five groups of up to six members were constituted. Each student received a script and each group the following material (Table 1):

Table 1. Resources available for experimentation.

\begin{tabular}{|l|c|l|c|}
\hline \multicolumn{1}{|c|}{ Reagents } & Amount $(\mathbf{m L})$ & \multicolumn{1}{c|}{ Material } & Amount \\
\hline Ethanol & 5 & Laboratory wash bottle & 1 unit \\
\hline Propan-1-ol & 5 & Beaker $10 \mathrm{~mL}$ & 6 units \\
\hline Butan-1-ol & 5 & Test-tube & 12 units \\
\hline 2-methylpropan-2-ol & 5 & Flask for disposal & 2 units \\
\hline Pentan-1-ol & 5 & Food colour & $5 \mathrm{~mL}$ \\
\hline
\end{tabular}

Each group had the task of developing a method to investigate the behavior of alcohols in aqueous systems and complete the Table 2 with observations. It was only a necessary technical clarification about the functions of glassware available.

Table 2. Space for recording the experimental data.

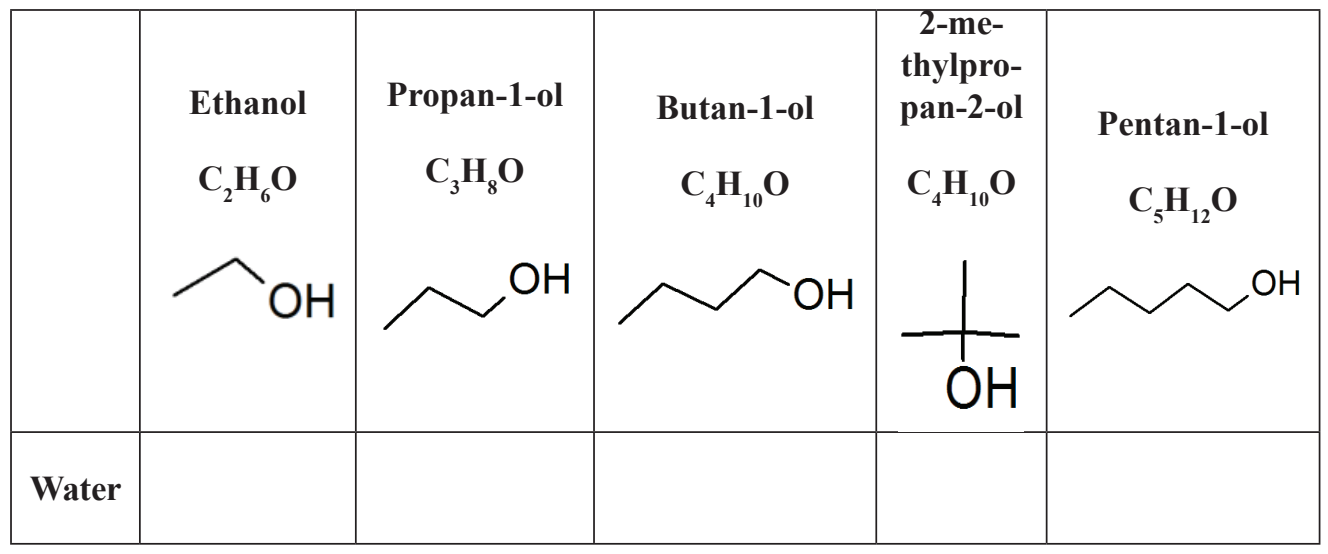

Still in this first meeting, it was requested the students to represent, in a drawing, the molecular interface of a homogeneous and heterogeneous mixture. 
The second meeting began on class with questions generated by leading misconceptions that appeared in the modelling activity (Figure 2a, 2b and 2c). The discussion was under the context of the experimental results (Figure 3 ). The analysis of the results is based on the misconceptions referred in the literature, according to a literature review published by Çalik et al (2005) and Mendes (2007).

Two questions were applied for written production. The first, requests the student to formulate an explanation for the differences in miscibility of propan-1-ol $\left(\mathrm{C}_{3} \mathrm{H}_{8} \mathrm{O}\right)$ and pentan-1-ol $\left(\mathrm{C}_{5} \mathrm{H}_{12} \mathrm{O}\right)$ in aqueous system.

The second provides the structural representation of butan-1-ol $\left(\mathrm{C}_{4} \mathrm{H}_{10} \mathrm{O}\right)$ and 2-methylpropan-2-ol $\left(\mathrm{C}_{4} \mathrm{H}_{10} \mathrm{O}\right)$ and prompts the student to formulate an explanation for the differences in miscibility of these compounds with the same molecular mass.

Three explanatory variables are amenable to be used to answer these two questions: structures, polarities and solute-solvent interactions. For example, some students can respond that propan-1-ol is more soluble than pentan-1-ol because is more polar and have a shorter chain and thus interacts better with the water, others may simply claim that propan1-ol is more soluble than pentan-1-ol because have a shorter chain. In Table 4, there are the complete results of that activity.

\section{Results and Discussions}

The modelling activity revealed some misconceptions (Figures $2 \mathrm{a}, 2 \mathrm{~b}$ and $2 \mathrm{c}$ ). The most frequents were the confusion between intermolecular forces and intramolecular forces, the idea that in a heterogeneous mixture there is no interaction solute-solvent and the conception that there is always a chemical reaction within the components of the mixture. One must note that in Figures $2 \mathrm{a}$ and $2 \mathrm{~b}$, the hydrogen bond is represented as a covalent bond. Some students believed in the synthesis of a new substance, others not knew how to represent a hydrogen bond.

The confusion between intermolecular forces and intramolecular forces was investigated by Treagust and Peterson (1989) and Peterson et al. (1989). They concluded that some of the student's difficulties in understanding the concept of chemical bonds may be linked to the bad understanding of intermolecular and intramolecular forces.

In Figure 2c, there is a layer separating the two phases of the heterogeneous mixture. Fourteen out of the 20 groups had these results in modeling activity, among these; eight groups have stated that there is no interaction between the molecules of the solute and solvent in a heterogenic mixture. Solomonidou and Stavridou (2000) conducted a study with 168 students, aged 13 and 14 years old, with the goal of diagnosing misconceptions in the process of building the concept of substance. The authors found that, initially, the students conceived substances as inert objects and the idea of interaction was gradually developed.

Prieto et al. (1989) also added that only the older students have begun to recognize the importance of solute-solvent interactions. However, in this context, the dissolution process always perceived as a chemical transformation.

In Figures $2 \mathrm{a}$ and $2 \mathrm{~b}$, some students represent a new substance, one with new propriety, different of the initial components. This misconception, that there is always a chemical reaction between the components of the homogeneous mixture, was noted by Ebenezer e Fraser (2001), Ebenezer e Erickson (1996) and Ebenezer e Gaskell (1995) in a research with the first-year chemical engineering students. Also, found that the ideas presented by 
the students suggest that their explanations of a chemical system focused on what they see. For example, after mixing sugar and water to form a liquid solution, some students have the idea that solid sugar converted into liquid sugar. Nussbaum (1985) argues that the difficulty to understand the homogeneous and heterogeneous systems in submicroscopic level should not surprise, as it requires a high level of abstraction and knowledge of atomic models.

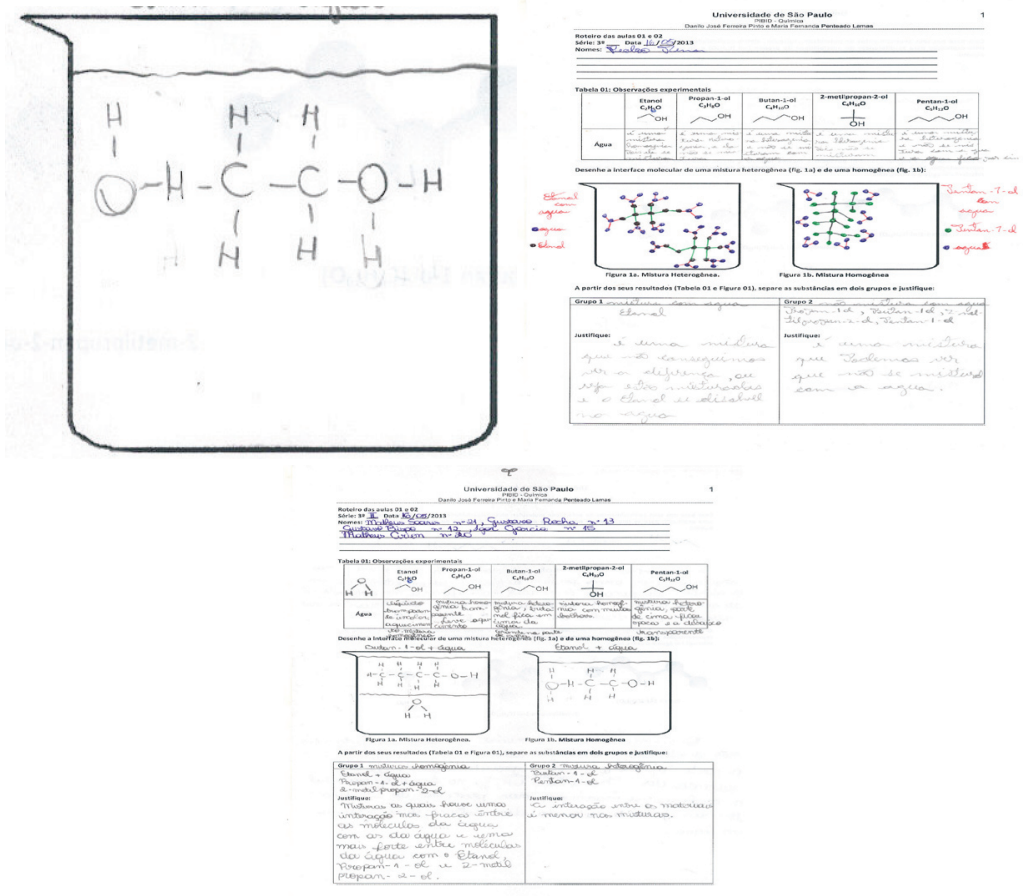

$2 a$

2b

2c

Figures 2: Main misconceptions resulting activity modelling.

Discussion of the experimental results (Figure 3) revealed how the results varied. The task of planning a method to investigate the solubility of alcohols was crucial for students analyze the problem and the objectives to be achieved. Not all groups have the same experimental results as some alcohols are miscible in certain fractions of water. This enriched the discussion of the concepts of miscibility to add a quantitative variable.

The main discussion involved the experimental results of the 2-methylpropan-2-ol in aqueous systems. In this test, 13 out of the 20 groups observed a homogeneous mixture, while the others observed a heterogeneous mixture. The teacher asked: "how can we explain the fact that 2-methylpropan-2-ol have dissolved in water in your experiment and not in the other group?". Students argued that some of the groups could have been wrong in the procedure. At this moment, the teacher request the groups to explain the procedure for the classroom and the differences noted on the blackboard. Observing the results, it was evident that the ratio of solute and solvent is determinant for the dissolution, as the groups that used larger fractions of water succeeded dissolving alcohol. 
Another important factor discussed about the dissolution was the energy supplied to the system by agitation. To raise this issue, the teacher asked: "If I better agitate the test tube that contains a heterogeneous mixture of 2-methylpropan-2-ol and water, will I be able to dissolve it?". Looking at Figure 3, students said yes, as the 2-methylpropan-2-ol is slowly dissolving in aqueous systems.

The teacher asked again: "If I better agitate the test tube that contains a heterogeneous mixture of pentan-1-ol and water, will I be able to dissolve it?". Some students said yes, as they think the agitation is the determinant factor of the extension of the dissolution. Then the teacher asked: "What if I put a very big amount of cooking salt in a glass of water and just shake? Will I dissolve all the salt?".

Blanco and Prieto (1997) conducted a study with students from 12 to 18 years old, investigating how learners internalize ideas about the concept of dissolution with a focus on external actions, such as agitation, for example. The authors concluded that pupils have the idea that the process of agitating affects the amount of solute that dissolves in a particular solvent and further unrest means more dissolution.

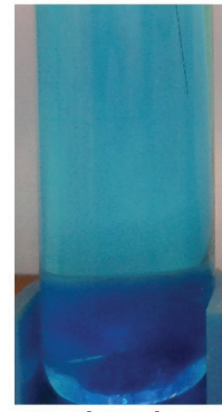

ethanol<smiles>CCO</smiles>

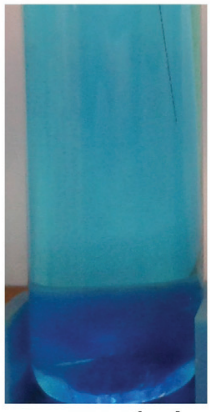

propan-1-ol

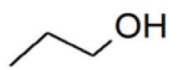

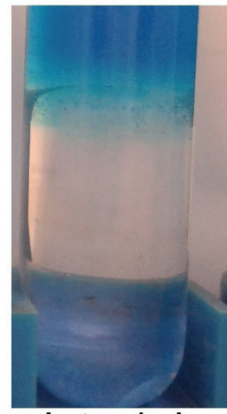

butan-1-ol

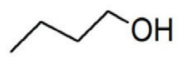

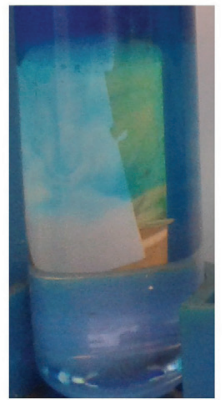

2-methylpropan-2-ol

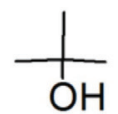

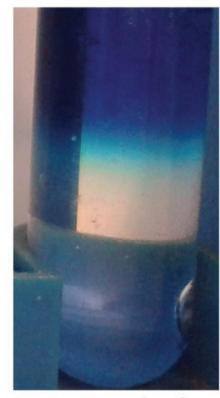

pentan-1-ol

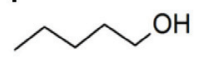

\section{Figure 3: Experimental result.}

The differences on miscibility of propan-1-ol $\left(\mathrm{C}_{3} \mathrm{H}_{8} \mathrm{O}\right)$ and pentan-1-ol $\left(\mathrm{C}_{5} \mathrm{H}_{12} \mathrm{O}\right)$ in aqueous systems were explored at the first question of the written production.

The second question provides the structural representation of butan-1-ol $\left(\mathrm{C}_{4} \mathrm{H}_{10} \mathrm{O}\right)$, 2-methylpropan-2-ol $\left(\mathrm{C}_{4} \mathrm{H}_{10} \mathrm{O}\right)$ and water (Figure 4) and prompts the student to formulate an explanation for the differences in miscibility of these compounds with the same molecular mass.
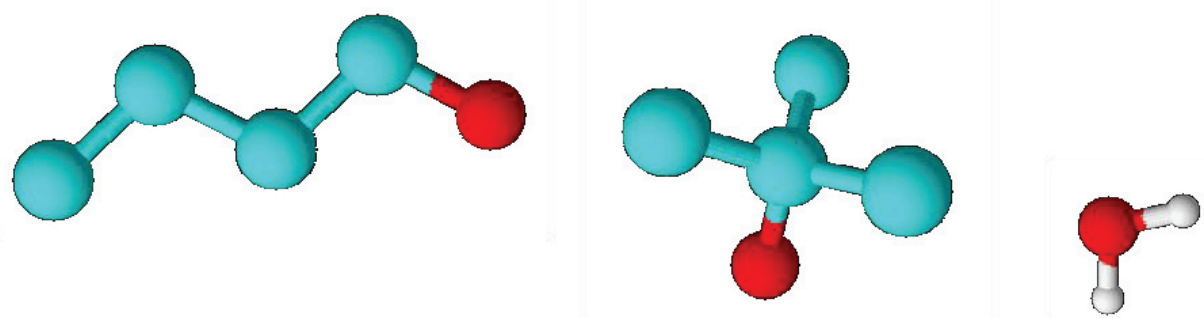

Figure 4: Representation of the structures of butan-1-ol $\left(\mathrm{C}_{4} \mathrm{H}_{10} \mathrm{O}\right), 2$-methylpropan-2$\mathrm{ol}\left(\mathrm{C}_{4} \mathrm{H}_{10} \mathrm{O}\right)$ and water, respectively. 
The analysis of the written productions presented three variables explanations that were used by the students to justify a higher (or lower) solubility of alcohols in water. These variables are the molecular structure, polarity and strength of solute-solvent interaction (Table 3).

Table 3. Results of the analysis of the written production.

\begin{tabular}{|l|c|c|}
\hline \multicolumn{1}{|c|}{ Variables explanations } & $\begin{array}{c}\text { Question 1 } \\
\text { (\%) }\end{array}$ & $\begin{array}{c}\text { Question 2 } \\
\text { (\%) }\end{array}$ \\
\hline $\begin{array}{l}\text { Molecular structure, polarity and strength of solute-solvent } \\
\text { interaction. Example: propan-1-ol is more soluble than } \\
\text { pentan-1-ol as it is more polar and has a shorter chain so } \\
\text { interacts better with water. }\end{array}$ & 29 & 19 \\
\hline $\begin{array}{l}\text { Molecular structure and polarity. Example: propan-1-ol is } \\
\text { more soluble than pentan-1-ol as it is more polar and have a } \\
\text { shorter chain. }\end{array}$ & 43 & 43 \\
\hline $\begin{array}{l}\text { Molecular structure and strength of solute-solvent interaction. } \\
\text { Example: propan-1-ol is more soluble than pentan-1-ol as it } \\
\text { has a shorter chain, so it interacts better with water. }\end{array}$ & 0 & 7 \\
\hline $\begin{array}{l}\text { Polarity and strength of solute-solvent interaction. Example: } \\
\text { propan-1-ol is more soluble than pentan-1-ol as it is more } \\
\text { polar so interacts better with water. }\end{array}$ & 7 & 3 \\
\hline $\begin{array}{l}\text { Molecular structure. Example: propan-1-ol is more soluble } \\
\text { than pentan-1-ol as it has a shorter chain. }\end{array}$ & 3 & 11 \\
\hline $\begin{array}{l}\text { Polarity. Example: propan-1-ol is more soluble than pentan- } \\
\text { 1-ol as it is more polar. }\end{array}$ & 11 & 3 \\
\hline $\begin{array}{l}\text { Strength of solute-solvent interaction. Example: propan-1-ol } \\
\text { is more soluble than pentan-1-ol as it interacts better with } \\
\text { water. }\end{array}$ & 0 & 7 \\
\hline
\end{tabular}

The most frequent misconception ( $3 \%$ in question one and $11 \%$ in question two), was that the "propan-1-ol is more soluble in water simply because it is smaller than pentan-1-ol." This conception that the particles of the solute can accommodate in the empty spaces of the solvent, derived from the idea that the particle size is a determinant factor for dissolution. Ebenezer e Erickson (1996) and Ebenezer and Gaskell (1995), identified this conception of solubility elicited from grade $11^{\text {th }}$ students at individual interviews.

Selley (1998) in his study of the history of the evolution of the concept of dissolution, has reported that the idea that the solute can be accommodated in the spaces of the solvent remained since Lucrecius, in 50 a.C., to the early XIX century.

Most students used the variables of microscopic to explain what was observed in the macroscopic field (Table 3). This outcome can be attributed to multiple modes of communication used, that is: experimental inquiry, activity of modelling, writing and discursive production. Similar patterns have been noted by other researchers (Chandler and Sweller, 
1991; Sweller and Chandler, 1994; Sweller, Chandler, Tieney and Cooper, 1990; Paas and Van Merrienboer, 1994), the results are consistent with the cognitive theory of multimedia learning, where corresponding words and pictures must be in the working memory at the same time in order to facilitate the construction of referential links between them.

To understand the dissolution in submicroscopic level, the student had to rearrange their previous conceptions and advance to a higher level of abstraction, as so many of the misconceptions described in the literature were identified in this work. They are related to the daily life of the student (Carmo and Marcondes, 2008). Thus, the various modes of communication used to contribute to the diagnosis of these concepts that were present in the mental models constructed by students.

\section{Conclusions}

Influenced by observable features in their life experiences, students provide macroscopic justifications to explain concepts related to the solution. Coherent explanations, in terms of a microscopic model to justify the dissolution process, were constructed by $72 \%$ of the students (in the first question, $62 \%$ at the second), indicating that a more complex conceptual level is no easy task when it concerns to teaching and learning.

Nevertheless, the effective participation of the student during the learning process, performing the experiment, comparing his ideas, arguing and discussing, lead to the construction of concepts.

The investigative experimentation, activity of modelling, discursive and written productions inside the multimodal concept, helped students to construct a more complex mental model about the relationships within the concepts of mixing, interaction and molecular polarity.

The strategy proposed here should serve as a guide and does not mark as a mandatory proposal in which students must follow the course indicated, but as a suggestion, so other educators would be able to plan a more meaningful education. Also, it is important to infer that a more successful education about the subject solutions should target the development of explanatory models by the students, which requires a greater time for reflections and discussions on a process to make possible to the student break up the barrier of concrete and evolve their thinking and explaining the phenomena involved.

\section{Acknowledgments}

The authors appreciate the cooperation of the students and staff of the School of Application FEUSP and CAPES for contributing to the improvement of teaching from the Institutional Scholarship Program Initiation to Teaching (PIBID).

\section{References}

Bachelard, G. (1996). Formação do espírito científico: Contribuição para uma psicanálise do conhecimento (pp. 314). Rio de Janeiro: Contraponto Editora LIDA.

Blanco, A., \& Prieto, T. (1997). Pupils' views on how stirring and temperature affect the dissolution of a solid in a liquid: A cross-age study (12 to 18). International Journal of Science Education, 19 (3), 303-315. 
Çalik, M., Ayas, A., \& Ebenezer, J. (2005). A Review of solution chemistry studies: Insights into students' conceptions. Journal of Science Education and Technology, 14 (1), 2950.

Carmo, M. P., \& Marcondes, M. E. R. (2008). Abordando soluções em sala de aula - Uma experiência de ensino a partir das ideias dos alunos. Química Nova na Escola, 28, 37-41.

Carmo, M. P., Marcondes, M. E. R., \& Martorano, S. A. A. (2010). Uma interpretação da evolução conceitual dos estudantes sobre o conceito de solução e processo de dissolução. Revista Electrónica de Enseñanza de las Ciencias, 9 (1), 35-52.

Chandler, P., \& Sweller, J. (1991). Cognitive load theory and the format of instruction. Cognition and Instruction, 8 (4), 293-332.

Chittleborough, G., \& Treagust, D. F. (2007). The modelling ability of non-major chemistry students and their understanding of the sub-microscopic level. Chemistry Education Research and Practice, 8 (3), 274-292.

Ebenezer, J., \& Erickson, G. (1996). Chemistry students' conceptions of solubility: A phenomenography. Science Education, 80 (2), 181-201.

Ebenezer, J., \& Fraser, D. (2001). First year chemical engineering students' conceptions of energy in solution processes: Phenomenographic categories for common knowledge construction. Science Education, 85 (5), 509-535.

Ebenezer, J., \& Gaskell, J. (1995). Relational conceptual change in solution chemistry. Science Education, 79 (1), 1-17.

Gonçalves, F. P., \& Marques, C. A. (2006). Contribuições pedagógicas e epistemológicas em textos de experimentação no ensino de química. Investigações em Ensino de Ciências, $11(2), 219-238$.

Hofstein, A., \& Lunetta, V. N. (2004). The laboratory in science education: Foundations for the twenty-first century. Science Education, 88 (1), 28-54.

Izquierdo, M., Sanmartí, N., \& Espinet, M. (1999). Fundamentación y diseño de las prácticas escolares de ciencias experimentales. Enseñanza de las Ciencias, 17 (1), 45-60.

Kress, G., Jewitt, C., Ogborn, J., \& Tsatsarelis, C. (2001). Multimodal teaching and learning: The rhetorics of the science classroom. London: Continuum International Publishing Group Ltd.

Marzano, R. J. (2000). Designing a new taxonomy of educational objectives. Thousand Oaks, CA: Corwin Press.

Mendes, D. M. S. (2007). Solubilidade e dissolução: Actividades experimentais. Repositório Institucional da Universidade de Aveiro. Retrieved December 5, 2013, from http://hdl. handle.net/10773/1304.

Moreno, R. (2005). Multimedia learning with animated pedagogical agents. In R. Mayer (Ed.). Cambridge handbook of multimedia learning (pp. 507-524). New York: Cambridge University Press.

Moreno, R., \& Mayer, R. E. (2007). Interactive multimodal learning environments. Special issue on interactive learning environments: Contemporary issues and trends. Educational Psychology Review, 19, 309-326.

Nussbaum, J. (1985). The particulate nature of matter in the gaseous phase. In R. Driver, E. Guesne, \& A. Tiberghien (Eds.), Children's ideas in science. (pp. 124-144). Milton Keynes, UK: Open University Press.

Paas, F. G. W., \& Van Merrienboer, J. G. (1994). Instructional control of cognitive load in the training of complex cognitive tasks. Educational Psychology Review, 6, 351-372.

Paivio, A. (1986). Mental representations: A dual coding approach. Oxford, England: Oxford University Press. 
Peterson, R., Treagust, D. F., \& Garnett, P. (1989). Development and application of a diagnostic instrument to evaluate grade-11 and -12 students' concepts of covalent bonding and structure following a course of instruction. Journal of Research in Science Teaching, 26, 301-314.

Prieto, T., Blanco, A., \& Rodriguez, A. (1989). The ideas of 11 to 14 -year-old students about the nature of solutions, International Journal of Science Education, 11 (4), 451-463.

Rapp, D. N. (2007). Mental models: Theoretical issues for visualizations in science education. In John K. Gilbert (Ed.), Visualization in Science Education (pp. 46-60), Holland: Springer.

Selley, N. J. (1998). Alternative models for dissolution. School Science Review, 80 (290), 7983.

Solomonidou, C., \& Stavridou, H. (2000). From inert object to chemical substance: Students' initial conceptions and conceptual development during an introductory experimental chemistry sequence. Science Education, 84 (3), 382 - 400.

Sweller, J., \& Chandler, P. (1994). Why some material is difficult to learn. Cognition and Instruction, 12, 185-233.

Sweller, J., Chandler, P., Tierney, P., \& Cooper, M. (1990). Cognitive load as a factor in the structure of technical material. Journal of Experimental Psychology: General, 119 (2), 176-192.

Treagust, D. F., \& Peterson, R. F. (1989). Grade-12 students' misconceptions of covalent bonding and structure. Journal of Chemical Education, 66 (6), 459-460.

Received 11 December 2013; Accepted 05 August 2014

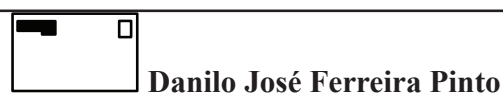

Undergraduate Chemistry Student, Chemistry Institute, University of São Paulo, São Paulo, Brazil. E-mail: danilo.colegio@gmail.com

Website: http://goo.gl/QYV6RM

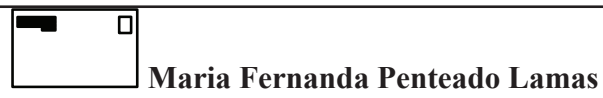

Master in Science Education, Chemistry teacher, School of Application, University of São Paulo, São Paulo, Brazil.

E-mail: mariferlamas@gmail.com

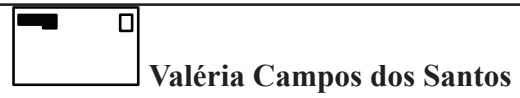

PhD., Student in Science Education, Faculty of Education, University of São Paulo, São Paulo, Brazil.

E-mail: valcampos07@hotmail.com

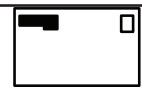

\section{Agnaldo Arroio}

PhD., Associate Professor, Faculty of Education, University of São Paulo, São Paulo, Brazil.

E-mail: agnaldoarroio@yahoo.com

Website: http://usp-br.academia.edu/AgnaldoArroio 